represent. Their value to science is sufficient to justify such enterprise. Let us hope that some day an investigator finds the time (and the money) to carry out a comparative osteological investigation of these fascinating survivors from the past.

F. E. Z.

An Irisil Sanctuary. The Rev. P. G. Kennedy, S.J. At the Sign of the Three Candles, Dublin. 12s. $6 d$.

This book professes to be no more than a guide to the North Bull bird sanctuary with a list of birds likely to be seen at particular times-indeed a modest claim. In fact it is also a delightful record, clearly and simply worded, of the observations of a naturalist and bird lover.

The North Bull is a sandy island three miles long on the north side of Dublin Bay; it is in a sense man-made, for until the North Bull Wall was built it was exposed at low tide only. In 1930 it became a bird sanctuary and it still remains so, though, as Father Kennedy graphically describes in a chapter called "Violation of Sanctuary", it is under constant threat of "Development". The first threat was to join the island to the mainland by dams at both ends and thus turn the tidal mud flats, beloved of wintering duck and waders, into a Blue Lagoon. This having been found impracticable, it was proposed to turn the island itself into an Amusement Park. Though the immediate danger of even this has been averted there is no feeling of security for the future. Can it be that Eire will allow its only significant bird sanctuary to disappear?

The number of species of birds to be seen on the North Bull is at its lowest in June and July, thirty-three, rising steadily to a hundred in December and January. Then it falls off equally steadily as the year progresses. There is no temporary increase in species during either the spring or autumn migrations and it would be interesting to compare the graph of species seen throughout the year with one from a similar place on the east coast of England.

Under each species we are given interesting notes on behaviour : starlings roosting in thick matted grass on the golf course, each with a hole to itself : a collection of finches, even including bramblings, coming to the shore to feed on jettisoned wheat : a stonechat following a groundsman, perching on his spade like a robin : short-eared owls soaring like buzzards : a bar-tailed godwit coming for scraps of food.

No descriptions of birds are given in this book and presumably, therefore, the illustrations are chiefly for ornament. All the 
photographs are good, but too many have already appeared elsewhere. The black and white sketches by Roland Green are excellent and will help in identification. The map, a small-scale reproduction from the Ordnance Survey, is practically useless. A sketch map giving the places named in the text would have put a finishing touch to this attractive little book. Let us hope that its publication will help towards saving the North Bull sanctuary.

\section{L. B.}

The Barotseland Journal of James Stevenson-Hamilton, 1898-99 (Central African Archives, Oppenheimer Series : 7). Chatto and Windus, Ltd., London. $35 s$.

This attractive publication-35 pages of introduction, 237 of text, and 8 of index, with ten illustrations in colour, frontispiece of the author, and a useful map-is a valuable addition to the Central African Archives' Series. It is a thrilling account of an expedition undertaken in 1898, with all the attendant dangers and hardships of those far-away pioneer days, to ascertain the navigability of the Zambesi and to determine the boundaries of Barotseland-now a part of present-day Northern Rhodesia. The introduction, by J. P. R. Wallis, is a remarkable historical document, mainly concerning the Barotse peoples, which provides an extremely interesting background to the endeavours and achievements of the expedition. Stevenson-Hamilton has always been a naturalist, and had it not been for the advent of Africa's first recorded rinderpest visitation a couple of years before he made his trip, no doubt the wild life would have figured even more prominently in his diary. As it is his records again and again refer to an absence of game due to the ravages of this deadly disease. It is interesting to note that Robert Coryndon-later to become Governor of Uganda and then of Kenya-at that time the British Resident in Barotseland, had extended a special measure of protection to the eland, an antelope which is particularly susceptible to rinderpest. Although stirring adventure, critical moments and praiseworthy resolution figure prominently, this diary also reflects history in the making, setting down clearly, faithfully, and immediately and without bias the folk, the conditions, customs, and ways of life, as they presented themselves to the writer.

The reference to the introduction to the Barotse country, in 1898, of the dread cattle scourge, pleuro-pneumonia, is of particular interest, for it is only now after more than fifty years 